\title{
Agro Informatics with its Various Attributes and Emergence: Emphasizing Potentiality as a Specialization in Agricultural Sciences-A Policy Framework
}

\author{
P. K. Paul ${ }^{1 \#}$, P. S. Aithal ${ }^{2}$, R. R. Sinha ${ }^{3}$, Ricardo Saavedra ${ }^{4}$, Bashiru Aremu ${ }^{5}$ \\ ${ }^{1}$ Executive Director, MCIS, Department of CIS, Information Scientist (Offg.), Raiganj \\ University, India. \\ ${ }^{2}$ Vice Chancellor, Srinivas University, Karnataka, India. \\ ${ }^{3}$ Pro Vice Chancellor (Asian Region), Commonwealth Vocational University, Kingdom of \\ Tonga. \\ ${ }^{4}$ Director \& Chair, International Programs, Azteca University, México. \\ ${ }^{5}$ Vice Chancellor, Crown University, Intl. Chartered Inc. (CUICI) Argentina Campus, Argentina.
}

\#corresponding author.

Type of Review: Peer Reviewed.

DOl: http://dx.doi.org/10.21013/jas.v14.n4.p1

\section{How to cite this paper:}

Paul, P.K., Aithal, P.S., Sinha, R.R., Saavedra, R., Aremu, B. (2019). Agro Informatics with its Various Attributes and Emergence: Emphasizing Potentiality as a Specialization in Agricultural SciencesA Policy Framework. IRA International Journal of Applied Sciences (ISSN 2455-4499), 14(4), 34-44. doi:http://dx.doi.org/10.21013/jas.v14.n4.p1

\section{(C) Institute of Research Advances.}

\section{(cc) EY-NC}

This work is licensed under a Creative Commons Attribution-Non Commercial 4.0 International License subject to a proper citation to the publication source of the work.

Disclaimer: The scholarly papers as reviewed and published by the Institute of Research Advances (IRA) are the views and opinions of their respective authors and are not the views or opinions of the IRA. The IRA disclaims of any harm or loss caused due to the published content to any party.

Institute of Research Advances is an institutional publisher member of Publishers International Linking Association Inc. (PILA-CrossRef), USA. The institute is an institutional signatory to the Budapest Open Access Initiative, Hungary advocating the open-access of scientific and scholarly knowledge. The Institute is a registered content provider under Open Access Initiative Protocol for Metadata Harvesting (OAI-PMH).

The journal is indexed \& included in CAS Source Index of Chemical Abstracts Service of American Chemical Society (USA), Index Copernicus (IC Value 85.27), WorldCat Discovery Service (USA), CrossRef Metadata Search (USA), WorldCat (USA), OCLC (USA), Open J-Gate (India), EZB (Germany) Scilit (Switzerland), Airiti (China), Bielefeld Academic Search Engine (BASE) of Bielefeld University, Germany, PKP Index of Simon Fraser University, Canada. 
IRA-International Journal of Applied Sciences

\begin{abstract}
Informatics is one of the important branches of Applied Sciences. It is a practicing area and also a field of study. The applications of Informatics in different areas and knowledge field has created various subjects and among these, one of important and emerging is Agricultural Informatics; which is the Information Science and Technology applications in the agriculture as well allied areas. In other words, techniques and technologies of both the fields i.e. Informatics and Agriculture lead the birth of Agro Informatics. The management and analysis of agricultural data with the help of Computing and IT may also be called as Agricultural Informatics. There are many allied nomenclatures of the field, but all are related and closely connected. In short, it is also called as Agro Informatics. Initially, it was treated only as a practicing area in the agriculture, horticulture, and veterinary sciences; but gradually it is a study area with different levels of programs at various universities and institutions, internationally. However, in the developed nation it is more common and widely available. Agro Informatics is an interdisciplinary field and very diverse. There are many features and functions, roles due to its timely need. This is a conceptual and policy-based research hence various aspects of Agro Informatics including its feature, functions, stakeholders, technologies including allied branches are mentioned. The paper also highlighted the proposed and possible programs of this field in academics in the field of Agricultural Sciences, as an empirical and policy research.
\end{abstract}

Keywords: Information Technology, Computing, Agricultural Informatics, Agro ICT, Environmental Information Sciences, Degrees, Interdisciplinary

\title{
Introduction
}

Information Technology is a vast field and combines with various sub-components of technologies viz. web technologies, database technologies, networking technologies, multimedia technologies, and traditional software technologies. However, apart from these, many technologies can be treated as a part of Information Technology [1], [5], [30]. And within these technologies, few are also emerging rapidly such as cloud computing, big data analytics, decision support system, artificial intelligence, expert system, geographic information system, remote sensing in the field of agriculture, and allied branches [2], [3], [11]. Agro-informatics as a branch increasing rapidly and importantlyAgricultural Informatics needs Strategic intervention of IT regarding which includes the coreagricultural input including the production and other hand, Output systems. Agricultural Informatics is required in some of the agro-industrial parts viz.-

- Integrate and facilitate trade,

- Food management and

- Security using technologies

- Supply Chain Management [4], [17], [31].

Universities internationally different academic programs on Agro Informatics and allied fields for developing manpower in Agriculture Informatics and allied fields viz. Agricultural Information Science, Agricultural Information Technology, Agricultural Information Science and Technology, Agricultural Information Systems [6], [10], [24].

However, research programs are little common in the field of Agricultural Informatics within the universities and research centers in Agriculture and also another merged area i.e. IT and Computing, etc [7], [29], [34].

\section{Objective}

The present paper entitled 'Agro Informatics concerning features, functions, and emergence as a discipline in Agricultural Sciences-An Analysis' is aimed with following (but not limited to) - 
- To know about the basics of Informatics; as a branch with its various fields and emerging areas.

- To get the basic features and characteristics of Agricultural Informatics with its stakeholders.

- To learn about the emerging applications and utilizations of Agricultural Informatics/ Information Systems in different areas of Agriculture and Allied Sciences.

- To know about the allied branches and nomenclature of Agro Informatics with existing programs in the universities.

- To propose the possible programs of Agricultural Informatics and allied areas in Agricultural Sciences at Bachelors and Masters.

- To find out the proposed and possible Doctoral, Post Doctoral and other research programs on Agricultural Informatics with Agricultural Sciences degrees.

\section{Agricultural Informatics \& Technological Components: Basics \& Emergence}

Agricultural Documentation was initially there and gradually many other areas have emerged but among these Agro Informatics was the first one. The following subjects also started later on as a field of study and research viz. Agricultural Information Systems, Agricultural Information Technology, Agricultural Information Science [12], [13], [34]. As Agricultural Informatics is a combination of two fields so from Information Technology part, the valuable sub-component or technologies includes (but not limited to)-

\section{Database Technology-}

Database technology is responsible for data-related activities viz. collecting, selecting, storing, processing as well as retrieving of data and the field Agricultural Informatics is responsible for data-related activities mentioned here logically and scientifically in Database or Similar Systems Management; and here all the data should be on Agriculture and allied fields only [14], [16], [27].

\section{Networking Technology-}

Networking Technology is responsible for the networking of the electronic systems, devices, and of course computers. Healthy and connected networking systems are very much important in the development of Agriculture Networks. Further, in the activities of connectivity of the computers and electronic products in the agro-industries and cultivators, etc Networking Technology play a leading role. In developing smart agriculture Networking technologies including wireless networks, IoT based systems, and converged networks are very much important.

\section{Web Technology-}

Web Technology is dedicated to website-related activities viz. designing, development, planning, monitoring, and management of the website include the web portal and allied systems. In the field of Agriculture, the branch web technology is most valuable and important for agricultural websites, Agro web portals, including for the marketing of the agro products and systems.

\section{Software Technology-}

Programs are the core of Software Technology; this is also called Software Engineering dedicated to the planning, designing, development, implementation, and management of software and applications. This is considered as the most vital part of IT. Regarding agriculture in designing, development, implementation, and management of agrobased apps and software; this technology plays a leading role [15], [18], [23]. 


\section{Multimedia Technology-}

Multimedia is another important part or component of Information Technology required for better and healthy information processing and representation. In the Agriculture domain, multimedia is useful in Agricultural content designing, Agro Products development, and also in software related to the agro and web portals. In Agricultural Information Systems design and development, Multimedia Technology plays a leading role as well[20], [25], 33].

These are the core technologies involved in Information Technology and apart from these few other emerging technologies also required in the Agricultural field or Agro Informatics field and depicted in Fig: 1.

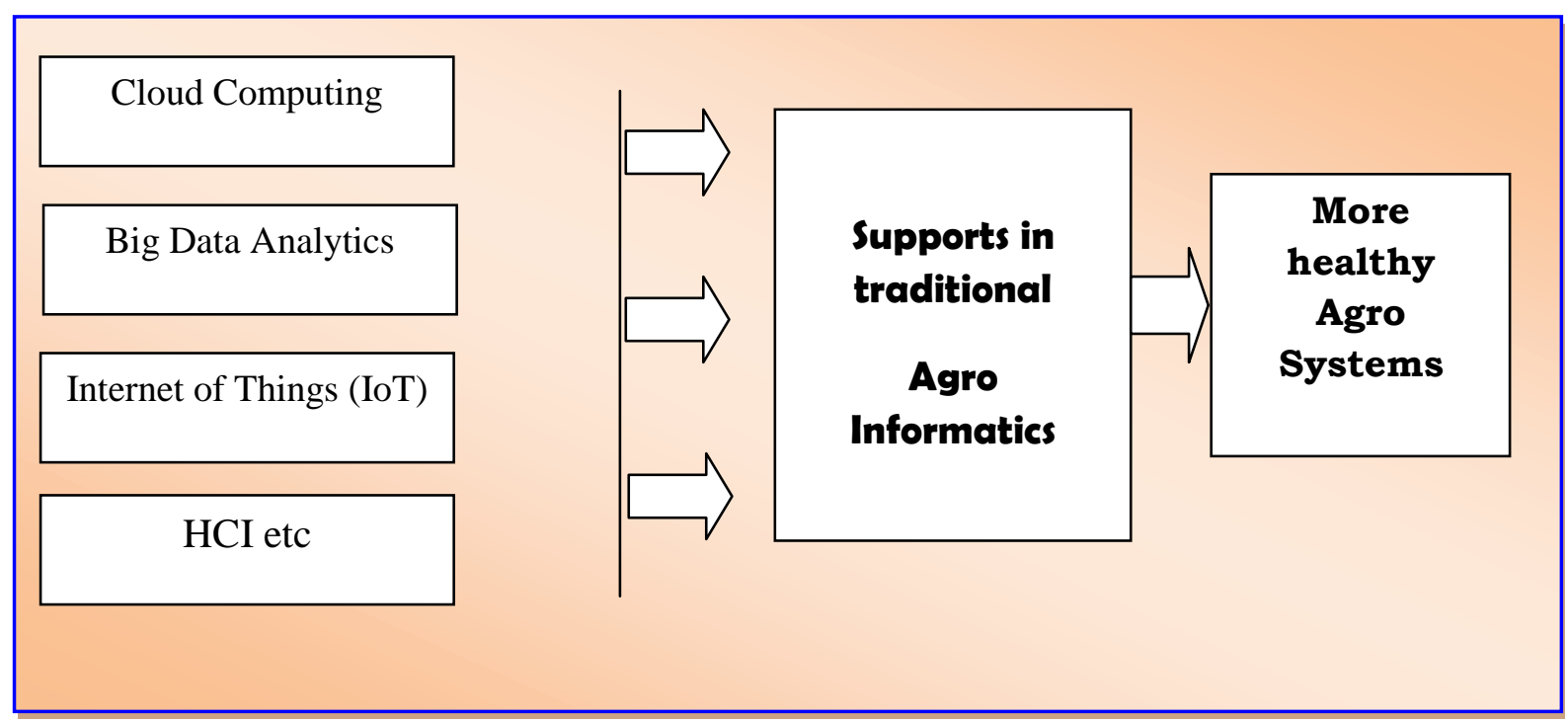

Fig: 1Emerging Technologies in traditional Agro IT resulting more advance Agro Systems

\section{Agricultural Informatics: Role, Development, Economy and Growth}

In a country like India, Agriculture is the main concern and also treated as a tool for development. And it is also applicable in other developing and undeveloped countries as well even in developed countries. According to expert Agro Informatics people can be a good reason for the employment generation throughout [21], [22], [40]. To date, there are millions of farmers having the small as well as marginal holdings and most of them are unaware of the modern cultivation methods and in this context, IT is the best tool and obviously, Agro Informatics may also be. Various challenges, issues on agriculture are already there such as drought, insect, pest infestations, heat, cold, flood, disease, weather and climate change, etc and in all these Agro Informatics is a great name. However, in following as well Agricultural issues are important to be noted viz-

- Food habits as well as nutritional requirements,

- Global trade scenario and changes,

- Technological and Systems development,

- Ecological aspects, etc 
And in all these areas, Agro Informatics can be an important name no doubt; directly and indirectly. Moreover, the strategic and methodological utilization of ICT in the Agricultural sector can lead to various aspects including the following (but not limited to) -

- Agricultural Input and Output systems,

- Integrate and facilitate Agro and allied trade

- Technology and food security in respect of Agro.

- Through effective in Agro Systems.

- Value-chain of the Agriculture

- Supply-chain Models in Agriculture and so on [26], [32], [36].

Information related technologies and fields viz. IT, ICT and Computing, etc in Agriculture is gaining worldwide. Moreover, here good demand is noticeable of the candidates having Agricultural Sciences and with good IT and Computing skills. Agro Informatics is responsible for global innovations as well as productivity in agricultural space, economical aspects and social development, etc [28], [35], [40]. According to a study it is noted that "agricultural graduates and agricultural informatics are responsible for the undertaking of Science and Technology based agricultural development including the ushering in agricultural dynamism in the country. It is a need of the hour to regarding the initiation of Agricultural Informatics and allied nomenclature or programs for in the subjects of IT, Computing, Informatics, Agriculture, Environmental Sciences, etc. However, the introduction of Agro Informatics could be easy in the subjects related to the technologies or Information or Agriculture. Here most important facets should be paid important as-

- Right skilling

- Knowledge with aptitude helps in the Agricultural field.

- Communication skills help in the Agricultural field.

- Entrepreneurship helps in the Agricultural field.

- Healthy leadership qualities that help in the Agricultural field etc.

Agricultural Information Technology or Informatics professional are dedicated to the development of various aspects of agriculture which includes the agricultural production, marketing, supply-chain management and these may help in agricultural activities including and may help to the following concern-

- Cultivators

- Agro or IT-based Industry and organizations

- Agro or IT-based research and extension services

- Agro or IT-based scientific organizations and institutions

- Agro or IT-based Educational Institutes.

Thus, Agro Informatics is dedicated to the healthy as well as sustainable Agro development and responsible for the complete development in many contexts [29], [35], [39]. There are many concerns in technological aspects in agro and some of them are provided in Figure 2. herewith. 


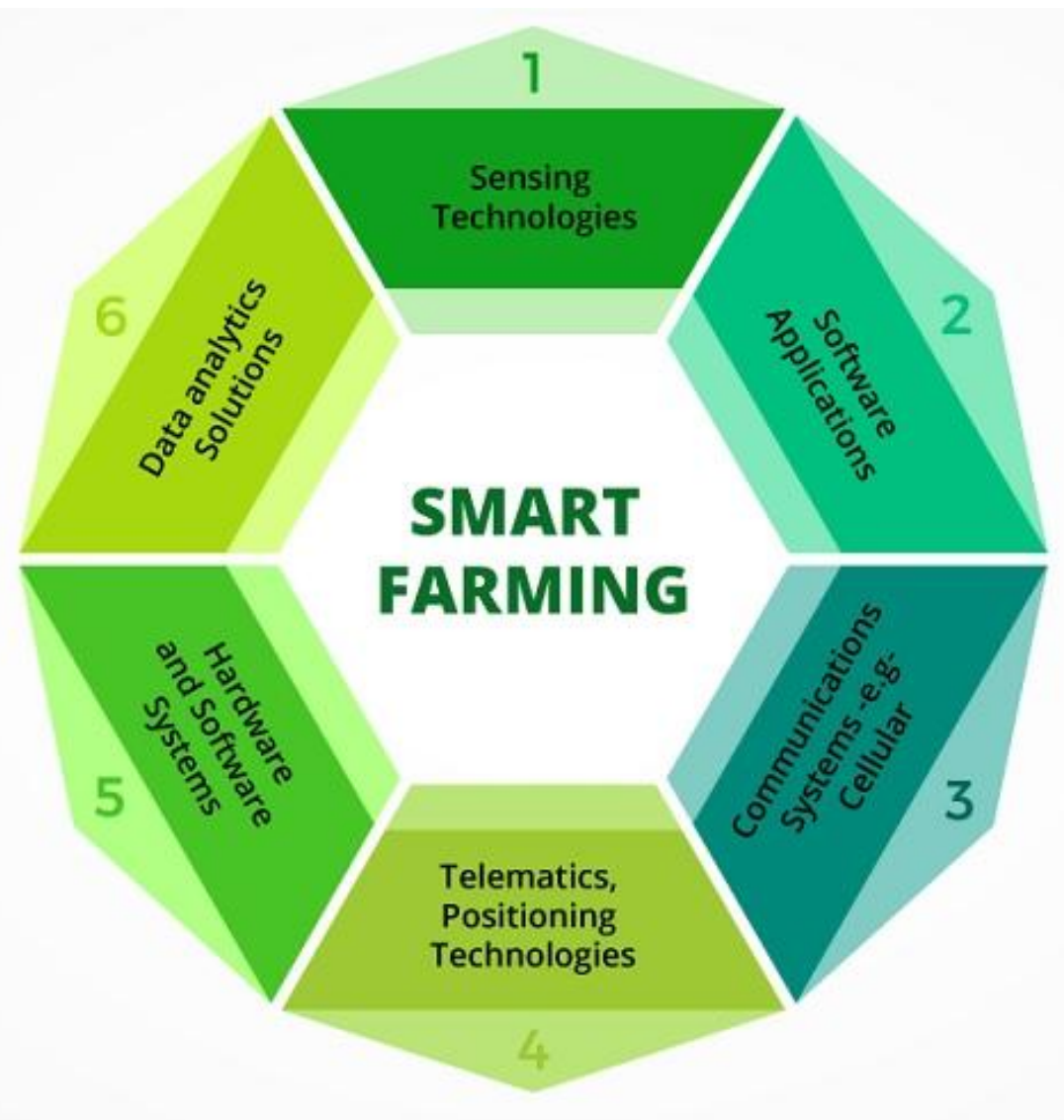

Fig:2-Technological aspects and fact Vis-à-Vis Agriculture

In enhancing the productivity in agriculture by different sorts and means Agro Informatics is a great name. Agricultural Informatics is a valuable field regarding study and research due to the following objectives (but not limited to)-

- To learn a comprehensive understanding as well as stakeholders of Agricultural-IT or Agricultural Informatics or allied fields.

- To learn the potential of sensor systems in measuring as well as monitoring of agricultural aspects including cultivation and post cultivation activities.

- Aspects and concern on managing, manipulating Agricultural related database designing and development properly possible with skill agro professional.

- To create the proper relationship and understanding not only of agriculture but also horticulture, ecology, forestry, etc for the development of a good ecosystem.

- With skilled products and graduates the systematic skills, interpret the agricultural data in a more meaningful sense for developing healthy and smarter Agricultural systems.

Hence it becomes an important field of study internationally and the following section provides a lot on this emerging concern. 


\section{Agricultural Informatics as an Academic Field, Job Opportunities and Possibilities}

Agricultural Information Science or allied as a field of study is now started in few universities However few important concerns on the emerging and mandatory few important are includes (but not limited to)--

- Introduction to Agricultural Sciences/ Systems.

- Remote Sensor applications in Agricultural and allied Systems.

- Spatial Systems in Agriculture/ food production.

- Information Management and Knowledge-Economy

- Sustainable Development

- Agricultural Marketing

- Big data and Analytics

- Ecological Agriculture and Globalization

- Decision making

- Cloud Computing and Agro Informatics [8], [9], [38].

Efficient designing and development of agricultural systems by providing services viz. in irrigation, storage, cultivation, weather and climatology, marketing, etc. Agro Informatics in production and other activities and thus it is concerned with technological, managerial and agro related jobs and some of the job titles are-

- Agro IT Facility Manager

- Weather and Climate Forecasting Expert

- Crop forecasting Expert

- Content Developer in Agriculture

- Agricultural Knowledge Manager

- Commodity Trader (Agriculture)

- ERP Manager (Agriculture)

- Agricultural Farm Manager

- Agricultural-Commerce Portal Developer and Manager

- Agricultural Financial Analyst

- Agricultural Supply Chain Manager

- Agricultural BPO Centre

- Crop and Agro Insurance Manager

- e-Governance Web Designer

- Agricultural Database Administrator

- Agricultural Web Developer

- Agricultural Software Engineer

- Agricultural Networking Experts

- Agricultural Business Informatics Experts, etc

Agriculture is one of the important concerns and here agricultural informatics is offered the services by which for healthy Agricultural development is possible. IT is responsible for the agricultural data and information activities ranging from collection, selection, organization, processing, managing, and disseminating. Further, as Agricultural Informatics is an interdisciplinary field hence the branch can be offered both in Agricultural Science or allied field and another hand in Information Science or allied filed. As far as this study is concerned possible programs in Agricultural Sciences are proposed in Table: 1 herewith. 
Table: 1-Possible Bachelor programs on Agro IT/ Informatics in Agricultural Science concentration

\begin{tabular}{|c|}
\hline Under Graduate \\
\hline BSc-Agriculture Sciences \\
(Agricultural Informatics/ Agro IT) \\
BS-Agriculture (Digital Agriculture) \\
BTech/BE- Agricultural Science \& Engineering \\
(Smart Agriculture) \\
BSc (Engg)- Agricultural Science\& Engineering \\
(Agricultural Informatics/ Agro IT) \\
BS/BTech-By Research \\
Agricultural Science\& Engineering \\
(Agricultural Informatics/ Agro IT/ Digital Agriculture/ Smart Agriculture)
\end{tabular}

As far as in Agricultural Science-based Agro Informatics is concerned apart from the exact fields/ nomenclature few other also proposed viz.-

- Digital Agriculture

- Smart Agriculture

- Agricultural ICT

- Agro Informatics \& IoT, etc

Whereas in Table: 2 possible Agricultural Science programs in concentrated on Agro Informatics at the Masters level is depicted in Table: 2 .

Table: 2-Possible Masters programs on Agro IT/ Informatics in Agricultural Science concentration

\begin{tabular}{|c|}
\hline Post Graduate \\
\hline MSc-Agriculture Sciences \\
(Agricultural Informatics/ Agro IT) \\
MS-Agriculture (Digital Agriculture) \\
MTech/ME- Agricultural Science \& Engineering \\
(Smart Agriculture) \\
MSc (Engg)- Agricultural Science\& Engineering \\
(Agricultural Informatics/ Agro IT)
\end{tabular}

Masters programs in Agricultural Informatics are very relevant and important as the program may be open for the already mature candidates and in Agricultural Sciences, they can specialize in this emerging field itself.

Table: 3-Possible Research-based programs on Agro IT/ Informatics in Agricultural Science concentration

\begin{tabular}{c}
\hline Research Programs \\
MS/MTech-By Research \\
Agricultural Science\& Engineering \\
(Agricultural Informatics/ Agro IT/ Digital Agriculture/ Smart Agriculture) \\
MPhil (Science) \\
Agricultural Science (Agro IoT/ Agro Informatics/ Digital Agriculture/ Smart \\
Agriculture) \\
PhD (Science) \\
Agricultural Science\& Engineering
\end{tabular}




$$
\begin{gathered}
\text { (Agro IoT/ Agro Informatics/ Digital Agriculture/ Smart Agriculture) } \\
\text { PhD (Engineering) } \\
\text { Agricultural Science (Agro IoT/ Agro Informatics/ Digital Agriculture/ Smart } \\
\text { Agriculture) }
\end{gathered}
$$

However, the research programs (referred to in Table:3) can be more helpful for already post-graduated with the Agricultural Sciences. In Science and Technology, both the specialization can be started.

\section{Suggestions}

Agro Informatics has huge potentiality and benefits to the cultivators, professionals, and stakeholders associated with the Agriculture field and those who are associated with the marketing of agricultural commodities. The following should be more important and valuable to be noted-

- Healthy investments are required due to the technologies involved in Agro Informaticsregarding its initial set up.

- Qualified, skilled staff and knowledgeable professionals are required for the designing, development, operation, and further management of Agro IT systems.

- Better connectivity of the internet and electricity are also needed for the good operation of Agro IT systems; here connectivity of different devices is also important and considered as essential.

- Manpower development is a challenging one as it is associated with various strategies. Initiation of a fullfledged program on Agro Informatics can be a difficult one due to certain reasons and in this context, specialization can be a good deal.

- Apart from the Agriculture, specialization of Agro Informatics can be also offered in Information Technology and allied fields.

- Collaboration, industrial tie-ups are required and important in current day context, here it should be done for the farm, technological organizations including the educational institutes and NGOsfor a healthy and solid manpower development and promotion of the Agricultural field.

- IoT, Cloud Computing, Big Data, Data Analytics, HCI, Usability Engineering, etc are also important and required for proper connectivity among such technologies.

\section{Conclusion}

Smart Agriculture is today considered as the most effective as well as for developing sustainable agricultural systems. Different emerging and modern technologies, innovative technologies are valuable in the agriculture and allied field. IoT and Cloud-based agriculture system will help in reducing the physical work of the cultivators for enhancing productivity and this could help in the water, optimization in a real-time manner, time-saving and postagricultural production, etc. With Agro IT/ Informatics many things are possible viz. humidity, temperature, soil, etc. Though there are many challenges in its proper implementation and practice of Agro Informaticsespecially the IoT, Cloud-based applications on a few aspects. Manpower development is another emerging issue and, in this regard, proper planning, educational policies, collaboration processes are highly required. Agro IT specialization may be started in IT and computing and Agriculture Sciences respectively. However, based on the infrastructure and status program can be started more specialized one viz. Agro Informatics \& IoT, Agro Informatics \& Cloud, Agro Informatics \& Data Analytics etc. Different bodies and organizations viz. Governmental organizations, agricultural firms, and companies, associations and trusts, etc for real implementation and further promotion of Agro-based 
systems. In a developing country like India, there are many initial challenges but all these can be overcome with proper policy and planning, etc.

\section{References}

[1] Abbasi, A. Z., Islam, N., \& Shaikh, Z. A. (2014). A review of wireless sensors and networks' applications in agriculture. Computer Standards \& Interfaces, 36(2), 263-270.

[2] Adão, T., Hruška, J., Pádua, L., Bessa, J., Peres, E., Morais, R., \& Sousa, J. J. (2017). Hyperspectral imaging: A review on UAV-based sensors, data processing and applications for agriculture and forestry. Remote Sensing, 9(11), 1110.

[3] Adetunji, K. E., \& Joseph, M. K. (2018, August). Development of a Cloud-based Monitoring System using 4duino: Applications in Agriculture. In 2018 International Conference on Advances in Big Data, Computing and Data Communication Systems (icABCD) (pp. 4849-4854). IEEE.

[4] Ahmad, T., Ahmad, S., \& Jamshed, M. (2015, October). A knowledge based Indian agriculture: With cloud ERP arrangement. In 2015 International Conference on Green Computing and Internet of Things (ICGCIoT) (pp. 333-340). IEEE.

[5] Aubert, B. A., Schroeder, A., \& Grimaudo, J. (2012). IT as enabler of sustainable farming: An empirical analysis of farmers' adoption decision of precision agriculture technology. Decision support systems, 54(1), 510-520.

[6] Babu, S. M., Lakshmi, A. J., \& Rao, B. T. (2015, April). A study on cloud based Internet of Things: CloudIoT. In 2015 global conference on communication technologies (GCCT) (pp. 60-65). IEEE.

[7] Balamurugan, S., Divyabharathi, N., Jayashruthi, K., Bowiya, M., Shermy, R. P., \& Shanker, R. (2016). Internet of agriculture: Applying IoT to improve food and farming technology. International Research Journal of Engineering and Technology (IRJET), 3(10), 713-719.

[8] Bauckhage, C., \& Kersting, K. (2013). Data mining and pattern recognition in agriculture. KI-Künstliche Intelligenz, 27(4), 313-324.

[9] Channe, H., Kothari, S., \& Kadam, D. (2015). Multidisciplinary model for smart agriculture using internet-of-things (IoT), sensors, cloud-computing, mobile-computing \& big-data analysis. Int. J. Computer Technology \& Applications, 6(3), 374-382.

[10] Chandraul, K., \& Singh, A. (2013). An agriculture application research on cloud computing. International Journal of Current Engineering and Technology, 3(5), 2084-2087.

[11] Ghobakhloo, M., Hong, T. S., Sabouri, M. S., \& Zulkifli, N. (2012). Strategies for successful information technology adoption in small and medium-sized enterprises. Information, 3(1), 36-67.

[12] Gill, S. S., Chana, I., \& Buyya, R. (2017). IoT based agriculture as a cloud and big data service: the beginning of digital India. Journal of Organizational and End User Computing (JOEUC), 29(4), 1-23.

[13] Gómez-Chabla, R., Real-Avilés, K., Morán, C., Grijalva, P., \& Recalde, T. (2019, January). IoT Applications in Agriculture: A Systematic Literature Review. In 2nd International Conference on ICTs in Agronomy and Environment (pp. 68-76). Springer, Cham.

[14] Goraya, M. S., \& Kaur, H. (2015). Cloud computing in agriculture. HCTL Open International Journal of Technology Innovations and Research (IJTIR), 16, 2321-1814.

[15] Guardo, E., Di Stefano, A., La Corte, A., Sapienza, M., \& Scatà, M. (2018). A fog computing-based IoT framework for precision agriculture. Journal of Internet Technology, 19(5), 1401-1411.

[16] Han, W., Yang, Z., Di, L., \& Mueller, R. (2012). CropScape: A Web service based application for exploring and disseminating US conterminous geospatial cropland data products for decision support. Computers and Electronics in Agriculture, 84, 111-123.

[17] Honkavaara, E., Saari, H., Kaivosoja, J., Pölönen, I., Hakala, T., Litkey, P., ... \& Pesonen, L. (2013). Processing and assessment of spectrometric, stereoscopic imagery collected using a lightweight UAV spectral camera for precision agriculture. Remote Sensing, 5(10), 5006-5039.

[18] Kamble, S. S., Gunasekaran, A., \& Gawankar, S. A. (2020). Achieving sustainable performance in a data-driven agriculture supply chain: A review for research and applications. International Journal of Production Economics, 219, 179-194.

[19] Kajol, R., \& Akshay, K. K. (2018). Automated Agricultural Field Analysis and Monitoring System Using IOT. International Journal of Information Engineering and Electronic Business, 11(2), 17. 
[20] Khattab, A., Abdelgawad, A., \& Yelmarthi, K. (2016, December). Design and implementation of a cloud-based IoT scheme for precision agriculture. In 2016 28th International Conference on Microelectronics (ICM) (pp. 201-204). IEEE.

[21] Liu, S., Guo, L., Webb, H., Ya, X., \& Chang, X. (2019). Internet of Things monitoring system of modern ecoagriculture based on cloud computing. IEEE Access, 7, 37050-37058.

[22] Manos, B., Polman, N., \& Viaggi, D. (2011). Agricultural and environmental informatics, governance and management: Emerging research applications. Z. Andreopoulou (Ed.). IGI Global (701 E. Chocolate Avenue, Hershey, Pennsylvania, 17033, USA).

[23] Muangprathub, J., Boonnam, N., Kajornkasirat, S., Lekbangpong, N., Wanichsombat, A., \& Nillaor, P. (2019). IoT and agriculture data analysis for smart farm. Computers and electronics in agriculture, 156, 467-474.

[24] Na, A., \& Isaac, W. (2016, January). Developing a human-centric agricultural model in the IoT environment. In 2016 International Conference on Internet of Things and Applications (IOTA) (pp. 292-297). IEEE.

[25] Nandyala, C. S., \& Kim, H. K. (2016). Green IoT agriculture and healthcare application (GAHA). International Journal of Smart Home, 10(4), 289-300.

[26] Nayyar, A., \& Puri, V. (2016). Smart farming: IoT based smart sensors agriculture stick for live temperature and moisture monitoring using Arduino, cloud computing \& solar technology. In Proc. of The International Conference on Communication and Computing Systems (ICCCS-2016) (pp. 9781315364094-121).

[27] Ojha, T., Misra, S., \& Raghuwanshi, N. S. (2015). Wireless sensor networks for agriculture: The state-of-the-art in practice and future challenges. Computers and Electronics in Agriculture, 118, 66-84.

[28] Othman, M. F., \& Shazali, K. (2012). Wireless sensor network applications: A study in environment monitoring system. Procedia Engineering, 41, 1204-1210.

[29] Ozdogan, B., Gacar, A., \& Aktas, H. (2017). Digital agriculture practices in the context of agriculture 4.0. Journal of Economics Finance and Accounting, 4(2), 186-193.

[30] Pau1, Prantosh Kumar Minakshi Ghosh, Dipak Chaterjee. (2014)Information Systems \& Networks (ISN): Emphasizing Agricultural Information Networks with a Case Study of AGRIS.Scholars Journal of Agriculture and Veterinary Sciences. 1 (1).

[31] Paul, Prantosh Kumar (2013) Information and Knowledge Requirement for Farming and Agriculture Domain.International Journal of Soft Computing Bio Informatics4 (2), 80-84

[32] Paul, Prantosh Kumar et.al. (2015) Agricultural Problems in India requiring solution through Agricultural Information Systems: Problems and Prospects in Developing Countries. International Journal of Information Science and Computing 2 (1), 33-40

[33] Paul, Prantosh Kumar et.al. (2016). Cloud Computing and Virtualization in Agricultural Space: A Knowledge Survey. Palgo Journal of Agriculture, 4(2), 202-206

[34] Paul, Prantosh Kumar et.al. (2015). Information and Communication Technology and Information: their role in Tea Cultivation and Marketing in the context of Developing Countries-A Theoretical Approach. Current Trends in Biotechnology and Chemical Research. 5 (2), 155-161

[35] Prasad, R., Kumar, V., \& Prasad, K. S. (2014). Nanotechnology in sustainable agriculture: present concerns and future aspects. African Journal of Biotechnology, 13(6), 705-713.

[36] Rajeswari, S., Suthendran, K., \& Rajakumar, K. (2017, June). A smart agricultural model by integrating IoT, mobile and cloud-based big data analytics. In 2017 International Conference on Intelligent Computing and Control (I2C2) (pp. 1-5). IEEE.

[37] Rezník, T., Charvát, K., Lukas, V., Charvát Jr, K., Horáková, Š., \& Kepka, M. (2015, September). Open data model for (precision) agriculture applications and agricultural pollution monitoring. In EnviroInfo and ICT for Sustainability 2015. Atlantis Press.

[38] TongKe, F. (2013). Smart agriculture based on cloud computing and IOT. Journal of Convergence Information Technology, 8(2).

[39] Tsekouropoulos, G., Andreopoulou, Z., Koliouska, C., Koutroumanidis, T., \& Batzios, C. (2013). Internet functions in marketing: multicriteria ranking of agricultural SMEs websites in Greece. Agrárinformatika/journal of agricultural informatics, 4(2), 22-36.

[40] Zamora-Izquierdo, M. A., Santa, J., Martínez, J. A., Martínez, V., \& Skarmeta, A. F. (2019). Smart farming IoT platform based on edge and cloud computing. Biosystems engineering, 177, 4-17. 